\title{
Matsalu mõisast ja selle omanikust
}

\author{
Tiit Rosenberg
}

\section{Matsalu mõis ja Hoyningen-Huened}

Ajaloolisel Läänemaal Karuse kihelkonnas asunud Matsalu rüütlimõis, mille kohta esimesed teated on allikates vähemalt 1560. aastast, kuulus alates 1867. aastast kuni mõisate võõrandamiseni 1919. aastal Hoyningen-Huenede perekonnale. Ebaselge algse päritoluga Hoyningen-Huenede aadlisuguvõsa on Balti provintsidesse jõudnud üle Kuramaa ja jagunenud vastavalt suguvõsa ja selle mõisateomandi laienemisele mitmesse harru. Siinseisse aadlimatriklitesse on nad kantud esmalt aastal 1620 Kuramaal, 1729 Eestimaal, 1785 Saaremaal ning 1818, 1898 ja 1905 Liivimaal. 1832. aastast kandis üks osa neist vene parunitiitlit. Matsalu Hoyningen-Huened kuulusid suguvõsa nn Lehtse harru, mille esindajad olid 19. sajandil valdavalt mõisnikud-põllumehed Järvaja Läänemaal (Genealogisches Handbuch 1931: 132). Lehtse, Kurge ja Aru mõisa (Ambla khk) omaniku, erurittmeister parun Nikolai Hoyningen-Huene (1807-1867) kolm poega - isalt päritud ülalnimetatud kolme Ambla kihelkonna mõisa omanik Friedrich (1843-1921), Matsalu mõisnik Nikolai (1845-1914) ning Ehmja ja Maalse (Martna khk) mõisa omanik (al 1869) Alexander (18481924) - olid ka ornitoloogid. Nendest Friedrich von Hoyningen-Huene on laiemalt tuntud kui lepideptoroloog, ornitoloog ja fenoloog (DBL 1970: 342-343; EBL 1940: 90; ETBL 2000: 397). 1921. aastal annetas ta Tartu Ülikoolile kodumaa linnupesade kollektsiooni (Postimees 1921).

Vendade haridustee enne mõisapidajaks hakkamist on piirdunud nähtavasti vaid kõrgetasemelise Tallinna Toomkooliga, millele järgnes tavapäraselt sõjaväeteenistus, abiellumine ja mõisapidaja-põllumehe elu isalt päritud, kaasavaraks saadud või enda soetatud mõisas.

Parun Nikolai Hoyningen-Huene juunior ostis Matsalu mõisa vastavalt 25. novembril 1867 sõlmitud ostu-müügi lepingule 85000 hõberubla eest endiselt kreisikohtunikult parun Friedrich Uexküllilt (1807-1877) (Wistinghausen 
1975: 233). Mõisaostu aastasse jäi vastsel mõisaomanikul ka isa surm ja abiellumine 5. novembril Ehmja mõisa omaniku parun Adolf Ungern-Sternbergi tütre Bertaga (1844-1924) ning Matsallu elama asumine. Seal või Haapsalus sündisid ka nende lapsed - 5 poega ja 2 tütart. Neist sai mõisapidajaks ja isa surma järel ka Matsalu omanikuks vanuselt teine poeg Alfred (1875-?) (Genealogisches Handbuch 1931: 132).

Suuruse poolest kuulus Matsalu mõis Eestimaa kubermangu mastaabis pigem suurte kui keskmiste hulka (Vahtre 1973: 75, 80, 116-117). 1859. aasta maaderaamatu järgi oli mõisal 48 talu- ja 2 vabadikukohta (EAA 891-1-98, Lagerbuch des Gutes Matzal 1859). Matsalu mõisa maad hõlmasid kokku üle 3300 ha, mida 1880. aasta maahinde järgi hinnati 27,80 adramaale, sellest mõisamaid oli 12,52 ja talumaid 15,28 adramaa väärtuses. Viimase maahinde järgi, kus vastavalt 1896. aasta maapäeva otsusele võeti lisaks seni arvestatud põllu-, heina- ja karjamaale arvesse ka metsad ja kalaveed, ületas Matsalu hindeväärtus 38 adramaad. Nii jäi Matsalu Karuse kihelkonnas pindalalt alla vaid Vatla mõisale, kuid adramaade arvu järgi, mis maksustamise alusena lähtus mõisa tulukusest, ületas ta nimetatut kolmandiku võrra. Majanduslik-halduslikult koosnes Matsalu mõis peamõisast, mis asus Matsalu lahe ääres, Saulepi kõrvalmõisast, mis oli enamasti välja renditud, kahest karjamõisast (Kännu ja Paevälja) ning küladest (Nelva, Liuste, Mäeküla, Petaaluse ja Nurmeküla) ja taludest, mis valdavas enamikus olid rendikohad. Talude päriseksmüügi poolest oli Matsalu üks tagasihoidlikumaid - esimesed 2 talu müüdi 1888. aastal ja aastail 1902-1915 müüdi veel 11 talu - kokku vaid ligi 32\% talumaadest 46952 rubla eest (EAA 3724-1-492, põllutööministeeriumi katastriosakond, toimik Matsalu mõisa talumaade hindamise kohta 1888-1929). Omanäolise barokse peahoonega Matsalu mõisaansambel oli välja ehitatud valdavalt 18. sajandi teisel ja 19. sajandi esimesel poolel (EA 1996: 31-32; Maiste 1996: 196). Mõisal oli 2 tuuleveskit, auruveski, meierei ja juustukoda (välja renditud), laialdane puuviljaaed koos puukooliga (soovijaile müüdi viljapuude ja marjapõõsaste istikuid), mesila (vurrimett müüdi 30-40 kopikat nael). Kindlaks tuluallikaks oli kalandus - eluskalu eksporditi otse Saksamaale (Adressbuch 1893/ 94: 147). Kuni kõrtside sulgemiseni (1900. aastal) tõi mõisale tulu ka kõrts. Hiljem on mõisa ettevõtete hulgas nimetatud ka katusekivide tootmist (Richter 1913: 467). 1892. aastast oli Matsalu mõisavalitsejaks Vaemla mõisa noorparun ja N. Hoyningen-Huene vastne väimees Gustav von der Pahlen (18671933), kellele äi andis 1897. aastal oma usaldusmehena ka notariaalselt laiad volitused (EAA 1341-1-122). Peatselt ka Hiiumaal Käina kihelkonnas Vaemla ja Aadma mõisa pidamist alustanud (algul isa kõrval pärijana, alates 1908. aastast omanikuna) parun G. von der Pahlen oli kohalike elanike hulgas suures 
lugupidamises (Rosenberg 2003: 45). Alates 1906. aastast oli Matsalu valitsejaks G. Hirsch.

\section{Kalapüügilubadest}

Rüütlimõisate eri aegadest pärit privileegide hulka kuulus ka mõisa piiresse jäävatel veekogudel või rannikul kalapüügi ainuõigus. Sellele tuginedes nõudsid rannaäärsed mõisad talupoegadelt mererenti. Lahemaa puhul, kus terve mererand kuulus mõisnikule, on teada, et ka pärast rannakohtade kruntimist jättis mõis müümisel harilikult endale kitsukese rannariba. Ta ei olnud kohustatud kalureid merele laskma. Läbipääsu, rannale ehitatud võrgumajade ja rannavees kalastamise eest kolme versta ulatuses nõudis mõis renti. 19. sajandi lõpul võeti mõnel pool sellena kalakümnist (1/10 saagist), mitmel pool kõrget raharenti (näiteks 50 rubla võrgupüügiõiguse eest, 35 rubla veel iga nooda pealt, peale selle veel teoorjus). Kõnnu rannas olnud odav mererent: 3 rubla pere pealt. Kolgas maksid rannamehed 20 rubla ja tegid 10 rubla eest tegu, mõned maksid ilma teota 30 rubla. Vabadikud maksid 10 rubla, saunikud tegid 12 kartulinoppimispäeva. Sellega said kõik ühesuguse õiguse merel käia (Tarvel 1983: 186). Aga kalapüügiõiguse eest tuli maksta ka Soomes, kuhu rikkamate kalakohtade pärast Viru rannikult püüdmas käidi - seal olevat Soome mõisnikust püügikoha omanik võtnud kas 3 rubla raha või pool tündrit silku iga paadi pealt. Seal, kus rand või saared ei kuulunud eraomanikule, maksti tasu (väiksem rahasumma) riigivõimu esindajale (Tarvel 1983: 187).

Siiski on 19. sajandi lõpul rannakalapüügi olud hakanud mitmel pool - nii Ranna-Virus kui ka Läänemaal, muutuma, arvatavasti seoses rannaäärsete talukohtade päriseksmüümisega. Nii kirjutati 1887. aastal Koogu-Aseri vallast (Viru-Nigula khk) Virulasele, et sealgi on mereranna elanikud mere eest mõisale renti maksnud, mitte küll rahaga, vaid kaladega:

Pü̈̈dmise juures tulnud igakord mõisa rannas pü̈̈dja ja selle kätte pidanud talunikud mererendiks kõik pü̈̈tud kammelseljad ja kõigist muudest kaladest kümnenda osa ära andma. Talunikud olla selle mererendi ärajätmise pärast ammugi palunud ja sel kevadel saanud nende palve täidetud. Nad lugenud "Virulasest" mere ja veeõiguse kohta käivaid seaduse punkte oma mõisa valitsusele ette ja avaldanud jälle eneste soovi ja palvet. Mõisavalitsus vaadanud tähendatud seaduse punktid üle, otsinud neid ka seaduse raamatutest ja jätnud siis nimetatud mererendi täitsa ära. Nü̈̈d pü̈̈da mõisa rannas pü̈̈dja ainult mõisa oma rannas, ei tulla sugugi valla ranna kohta, nagu enne ja valla ranna elanikud ei 
minna ka mõisa ranna kohta. Mõlemad pü̈̈da rahuga igaüks ainult oma rannas ja kumbki ei nõuda kummagi käest miskisugust renti.... - Ka Läänemaa rannas olla mõnes kohas tähendatud seaduse peale toetamise põhjusel mererent ära jäetud. M. vallas toodud küll talunike noodad valla ranna kohalt merest kord välja, aga kui need uuesti sinna tagasi viidud, siis jäänud asi vagusi ja valla rahvas pü̈̈da oma rannas ilma mererendita (Virulane 1887).

Kuna Matsalu mõisas olid nähtavasti just rannaäärsed talud müümata ja rannaõigus mõisa päralt, siis on seal püsinud ka müügilubade praktika. Muidugi tekitas see kõik ka müügiõiguse lunastamisest möödahiilimist ja kohtuasjugi. Viimaseid pole Matsalu kohta teada, küll aga on säilinud mitu kohtuasja Nikolai von Hoyningen-Huene vennale kuulunud Ehmjast. Nii kaebas Alexander von Hoyningen-Huene 1903. aasta juunis-juulis Martna vallakohtusse mitu talupoega kevadel Ehmja mõisa meres loata kalapüügi pärast, nõudes igale 4 rubla trahvi määramist. Vallakohus, kes hoidis ilmselgelt patustanute poole, langetas kõigil juhtudel ühesuguse otsuse: lähtudes sellest et püügiõiguse hind oli 1 rublast kuni 10 rublani ja et nõudja oma nõudesummat kohtus ei tõendanud, mõistis kohus kaebealustelt mõisniku kasuks vaid miinimumsumma - 1 rubla tasumist (EAA 2600-1-1803 ja 1804).

Ülaltoodust lähtudes võib pidada Matsalu mõisas 1906. aastal rakendatud püügilubade korraldust tavapäraseks ja hinda mõõdukaks või koguni soodsaks.

\section{Nikolai von Hoyningen-Huene isikust}

Tänu mitmele temaga seotud kohtuasjale osutus Matsalu parun üpris omapäraseks ja stereotüübist ilmselt hälbivaks isikuks. Nagu Eestimaal rüütelkondliku maaomavalitsuse puhul tavaline oli, pidasid mõisnikud kuni 1887.-1889. aasta justiitsreformini mitmesuguseid politsei-ja kohtuameteid valdavalt ühiskondlikus korras - auametina. Alaliselt oma mõisas elavate mõisaomanike seast valiti rüütelkonna maapäeval tavaliselt kolmeks aastaks adra(resp haagi)kohtunikud ja kihelkonna- ning kreiskohtu kohtunikud ja kaasistujad (assessorid) (Dellingshausen 1994: 44-46).

Mõisnikupõlve hakul lühikest aega Läänemaa meeskohtu assessori ametis olnud Nikolai von Hoyningen-Huene on mitmel korral sattunud vastuollu oma seisusekaaslastega, hiljem aga uute vene kohtuvõimudega. Nii algatati 1872. aastal tema vastu kohtuasi Ranna-Lääne adrakohtuniku von Lilienfeldi aadressil kasutatud sobimatu väljendusviisi tõttu, kuna parun kritiseeris üht viimase langetatud otsust kui meelevaldset ja ebaseaduslikku. Eestimaa Ülem- 
maakohtuni jõudnud asi lõppes paruni sunnitud vabandamisega (EAA 858-16566 ja 6591; EAA138-1-463). 1888. aastal algatati Läänemaa Meeskohtus paruni vastu hagi politseieeskirja rikkumise asjus seoses adrakohtuniku ründega paruni koerte poolt (EAA 863-1-982 ja 3768). Märksa tõsisem oli aga parun Huene kui ametiisiku enda vastu tõstetud süüdistus, mille tehiolud ometi siinsete kohtuaktide nappuse tõttu (üksikasjalikumad materjalid on arvatavasti koondunud kohtuasja käigus Senatisse Peterburis) mõneti ebaselgeks jäävad. Nimelt on parun Huene märtsis 1885 Ranna-Lääne adrakohtunikuks nimetatud, kuid juba oktoobris 1886 ametist vabastatud, süüdistatuna ametivõimu ületamises või koguni ametialases kuriteos. Süüdistus läbis mitmeid instantse, jõudes detsembris 1887 Eestimaa Ülemmaakohtusse, sealt 1889. aasta Balti kubermangude kohtureformi harjal edasi Peterburi kohtupalatisse, kus parun Huene kolmeks kuuks kinni mõisteti, ning lõpuks Senatisse, mis 1891. aastal asendas nimetatud karistuse kolmenädalase vangistusega (EAA 858-1-1139 \& 1155; Tallinna Sõber 1885; Olevik 1886; Postimees 1891). Et Matsalu parun kohtuasjaks ajendi andnud teos õigluse ja talurahva huvides on toiminud, tunnistab mitmete Läänemaa valdade kirjutajate ja vallavalitsuste tänukiri parajasti kõrgemate kohtute uurimise all olevale endisele adrakohtunikule, mille kohta mitmed eesti ajalehed teate avaldasid. Nimelt tänati selles kirjas parun Huenet, et see nende seas õiguses ja auuses kohut on mõistnud, õigetele kaitsmiseks ja ülekohtustele nuhtluseks. Tänutunnistuse andjad soovisid koguni, et neile edespidi veel palju niisuguseid kohtuhärrasid tõuseks, kui parun Huene on (Virulane 1886; Oma Maa 1887: 59).

1880. aastatel oli Matsalus Hoyningen-Huene perekonna koduõpetajaks kahel korral kirjanik Eduard Brunberg-Bornhöhe (1862-1923). Vaatamata sellele, et töö polnud koormav, tundis vabameelsete vaadetega koduõpetaja end põliste aadlike konservatiivses õhkkonnas üksildasena. Mõisnikku ennast on ta iseloomustanud jaanuaris 1883 Matsalus dateeritud kirjas järgmiselt:

Parun on küll räigelt konservatiivse iseloomuga, arvestab aga ka teiste inimeste arvamust, niikaua kui see paljalt arvamuseks jääb. Ta peab mind täielikuks materialistiks ja nihilistiks, mis teda aga ei takista mind kõige viisakamalt kohtlemast.

1887. aasta septembris Matsalust E. Franzile saadetud kirjas on E. Bornhöhe kurtnud:

Kuudas elasin ma nü̈̈dsega võrreldes paradiisis. Siin on kõik autokraatlikust mõisahärrast kuni kõige noorema põrsani täis feodaalset vaimu. Ma teen kõigele sellele üsna kangekaelset opositsiooni, ilma et keegi muutuks selle läbi targemaks - ja minule sarnasemaks. 
Vaid mõisniku tütar, 16-aastane paruness Agnes Hoyningen-Huene (1872-?) olevat suhtunud nooresse õpetajasse erilise poolehoiuga. Koos tehtud pikki saanisõite, käidud ratsutamas ja kasutatud häid uisutamisvõimalusi Matsalu lahel. Väidetavasti on Läänemaa-aastad E. Bornhöhe loomingusse vähe otseseid jälgi jätnud. Siiski on oletatud, et üheks kaugeks vastukajaks sellest perioodist on naispeategelase Agnese nimi Vürst Gabrielis (1893) (Kuningas 1987).

Laiemalt sai Matsalu parun Huene tuntuks detsembris 1905 Eestimaa rahvale adresseeritud avaliku kirja ja sellele järgnenud kohtupidamisega tema üle vene riigivõimu ja vene ametnike halvustamise pärast. N. Hoyningen-Huene, kes kuulus ilmselt ettenägelikumate ja eestlastega kokkuleppimist võimalikuks pidavate Eestimaa mõisnike hulka, oli talurahva silmis omandatud soodsa maine tõttu sobivaim isik kriitilises olukorras rahva poole pöörduma. Ebaselge on vaid, kas see oli tema eraviisilise või rüütelkondliku initsiatiivi tulemus. Päris kindel pole ka parun Huene ainuautorlus - nimelt on hiljem viidatud ka Karuse pastorile ja Läänemaa praostile Immanuel Paul Rinnele kui pöördumise koostajale (Kaja 1930). Tallinnas A. Kullapi trükikojas eesti keeles 8-leheküljelise brošüürina trükitud ja laialt levitatud (seda jagatud tasuta kõikjal kirikute juures ja levitatud ka ajalehtede Valgus ja Revaler Beobachter lisana) Avalik kiri Eestimaa rahvale algas sõnadega Armas rahvas! (EKM EKLA F. 183, M 8:1, L. 65-68, eksemplar A. Kruuspere kirjakogus). Parun püüdis eestlastele selgitada, et mõisnike ja talurahva kunagise patriarhaalse vahekorra on rikkunud vene ametnikud ning rahva on üles ässitanud omakasupüüdlikke eesmärke taotlev ajakirjandus ning sotsialistid. Püüdes anda vastust küsimustele, mispärast meie isamaa elanikke nüüd üksteise vastu üles kihutatakse, kas pole me mitte ühe keha liikmed, ühe uuri rattad, millest igal ühel oma funktsioon, pöördus parun ka ajaloo poole, sest:

Kahju, väga hale on see, et meie isamaa elanikud oma isamaa minevikku ei tunne ja sellepärast ka ei tea, kelle pärast Jumala vits teda peksis, mis põhjuse peal orjus algas, ja mis verevaeva uue elu asutamine Baltimaale maksis. Sellepärast et rahvas seda ei tea, on rahva kihutajate töö väga kerge; aga see piits ja see orjus ei ole siin kunagi nii hirmus olnud kui mõnes teises riigis...

Ühelt poolt püüdis parun eestlastele selgeks teha nende eksiarvamist, nagu oleks nemad selle maa pärisrahvas (enne neid olnud siin teisigi rahvaid, kellest gootid siit Rootsimaale rännanud ja kunagi ulatunud siiamaani ka kuningas Hermanrichi aegne Ida-Gooti riik), teiselt poolt aga seda, kui ühekülgselt tuntakse viimase 200 aasta ajalugu. Viimase näiteks tõi ta nii vene tsaaride piinahimu (Ivan Julma ja Peeter I nimepidi küll nimetamata), Põhjasõja-aeg- 
set feldmarssal Šeremetjevi rüüsteretke metsikusi ja laastamist kui ka nüüdisaegsete vene ametnike ennasttäis käitumist ja omavoli. Õigustades mõisnikke (...kusagil pool maailmas ei kanna mõisnikud ehk parunid nii suurt koormat kui just Baltimaal. Kes seda ei usu, pruugivad aga üle piiri Pihkva ehk Peterburi kubermangu vaadata, ehk ka teisele poole Ladoga järve, kus ka Eesti sugu rahvas elab...), tõstes esile ennast (... ligemale viissada aastat on minu sugu seda maad kaitsenud, harinud ja häda ja vaeva temaga jaganud; ise ma olen siin sündinud, sellepärast ta on minu täis armas isamaa...) ja süüdistades rahvast tabanud hädades poolharitlasi ja sotsialiste (...iga rumalus ja vale leiab ju uskujaid ja jüngrid. Meie isamaa on praegu nagu hullumaja, kus vahel aru ei saa, kes hull ja kes tohter on... Teie teate... teie näete ja teie hing tunneb, et... surma varjud meie armsa isamaa ukse ees seisavad), kutsus parun Huene Eestimaa rahvast üles üksmeelele ja leppimisele:

See aeg on alganud, kus suur Jumal jälle nisu sõelub ja aganad tuulesse viskab, ja selle pärast lepitame ruttu oma kodust riidu, anname üksteisele kõik sü̈̈d andeks ja astume kui ühemeelne Jumala rahvas vaenlaste vastu. Minu elav usk, minu isamaa armastus on mind sundinud seda avalist kirja selle rahva hulka saatma, keda mina lapsepõlvest tunnen ja kellele ma täiest südamest edenemist ja õnne soovin.

Brošüüri olevat levitatud eriti Matsalu ümbruskonna valdades, kuid ka sealne rahvas olevat lugenud seda naiivset rahvale määratud avalikku kirja. Muiates, sest rahvasse oli sajandite jooksul kasvanud enam viha mõisnikkude kui Vene valitsuse vastu, kerge polnud seda arvamist muuta (Looring 1935).

Paruni pöördumine ei jäänud ka laiema vastukajata. Kui eesti ringkonnad ja ajalehed suhtusid sellesse valdavalt distantseeritult või umbusuga, siis vene võimud ja seltskond nägid selles vaid venevastast ässitust ja lugupidamatust võimu vastu (Postimees 1906; Säde 1906). Viimane ajendaski võime parun Huene vastu kohtuasja algatama, süüdistades teda mitmest rahvusest elanikke ühe teise vastu kihutamises (karistusseadustiku § 1036). Tallinna ringkonnakohtu istung toimus Haapsalus 16. mail 1906. Publik koosnes peaaegu eranditult vene väikeametnikest ja nende naistest, kuna baltisaksa aadlikest oli peale süüaluse kohal vaid kaks tema sugulast. Parun Huene kaitses end vene prokuröri vastu ja kohtunike ning vaenulikult häälestatud publikumi ees ise, tehes seda väga oskuslikult ja südilt. Rumalasse olukorda jäänud kohus pidi süüdistuse ümber kvalifitseerima ja kuna esitatud süüdistust tõendada ei suudetud, siis langetati kohtuotsus hoopis toore ja kombeta ülalpidamise eest "ülema" vastu tema otsekohese teotamise pärast sõimu ja halvustavate kõnede eest või “ülema” suusõnalise teotamise eest kohtuasja harutamise ajal (§ 394). Selle põhjal mõisteti parun Huene kaheks kuuks vangi koos kohtukulude tasumise- 
ga. Selle peale olevat Tallinna Vene ajaleht Revelskije Izvestija triumfeerinud - üks sakslane, üks parun, mõisteti süüdi eestlaste venelaste vastu ässitamise pärast (Rigasche Rundschau 1906; Valgus 1906). Siinkohal jääb paraku veel lahtiseks, kas Huene ka tegelikult kinni istus.

Parun Huene avalikul kirjal oli ka järellugu. Nimelt ajendas see üht Läänemaa ärksamat talunikku, Vaikna valla Hiie talu peremeest Hans Habermanni koostama augustis 1910 omapoolset pöördumist Eestimaa mõisnike poole, jagamaks neile näpunäiteid, mida teha, et neil mõisates töölistest puudus ei tuleks ja poliitiline võim nende käes püsiks. Teades, et mõisnike hulgas on kaaluv sõna Matsalu parun Huenel, adresseeris ta pöördumise Huene nimele, kutsudes viimast oma kodutallu endaga kohtuma, et suusõnaliselt asjast lähemalt rääkida. Huene saigi kutse kätte ja vastas 26. septembril 1910 kutsujale: Teie kiri mina olen kätte saanud ja kahjatsen väga, et mina teitega suu suu vasto ei saa räkida. Täna mina tõttan Tallinna ja selle perast on mul vähe aega kirjutamise jäuks ja selle perast ma aga vastan Teitel lühidalt...

Dialoog piirdus sellega ja eesti taluniku targad soovitused mõisnikele (lihtrahva keel ära õppida, nendega iga päev seltsida, neid töös ise juhatada ja õpetada, nendega kenasti ringi käia jms ...Üleüldse peate endid igas asjas rahvaga ühendama ja tingimata oma vana uhkuse ära heitma...), jäid edasi andmata (Kaja 1930).

Veel kord toodi parun Huene avalik pöördumine 1905. aastast avalikkuse ette I maailmasõja algul, kui parun ise juba enam kui pool aastat Karuse surnuaial puhkas. Seekord tarvitati seda saksavastase viha ülespuhumiseks, demonstreerimaks baltisaksa mõisnike venevastasust ja ebalojaalsust. Seejuures mainiti ka fakti, et Matsalu paruni kaks nooremat poega olid õppinud Saksamaal ja saanud Saksa ohvitserideks (Päevaleht 1914).

\section{Arhiiviallikad}

$\mathrm{EAA}=$ Eesti Ajalooarhiiv

EKM EKLA = Eesti Kirjandusmuuseumi Eesti kultuurilooline arhiiv, F. 183, M 8:1, L. 65-68, eksempar A. Kruuspere kirjakogus.

\section{Kirjandus}

Adressbuch = Kröger, Alexander Wilhelm (toim). Ehstländisches Verkehrs- und Adressbuch für 1893/94. Riga: Im Selbstverlage des Herausgebers.

Dellingshausen, Eduard von 1994. Kodumaa teenistuses. Eestimaa Rüütelkonna peamehe mälestused. Tallinn: Olion. 
EA $1996=$ Villem Raam (üldtoim). Eesti arhitektuur 2. Tallinn: Valgus.

DBL 1970 = Welding, Olaf (koost) \& Lenz, Wilhelm (toim). Deutschbaltisches biographisches Lexikon 1710-1960. Köln \& Wien: Böhlau.

EBL 1940 = Hoyningen-Huone. Tarvel, P. (peatoim). Eesti biograafilise leksikoni täiendusköide. Tartu: K. Mattiesen (http://www2.kirmus.ee/grafo/index.php?ID=231 - 2. november 2009).

ETBL 2000 = Eesti teaduse biograafiline leksikon I. Tallinn: Eesti Entsüklopeediakirjastus.

Genealogisches Handbuch 1931 = Genealogisches Handbuch der baltischen Ritterschaften. Teil Estland, Bd 3, Lieferung 2. Görlitz: Starke.

Kaja 1930 = Hans Hebermanni läkitus Eestimaa mõisnikkudele. Üleskutse, mille eest Matsalu parun N. Hoyningen-Huene sai 2 kuud kinni istuda. Läänemaa talumehe prohvetlik ettenägemine. Kaja 7, 9. jaanuar, lk 3.

Kuningas, Oskar 1987. E. Bornhöhe Matsalu-aastaist. Töörahva Lipp 19. veebruar.

Looring, Aleksander 1935. 1905. a. revolutsioon Läänemaal 2. Eesti Kirjandus 11, 481-499.

Maiste, Juhan 1996. Eestimaa mõisad. Tallinn: Kunst.

Olevik 1886 = Sõnumid Eestimaalt. Valitsus. Kord. Kohus. Olevik 36, 1. september, $\mathrm{lk} 2$.

Oma Maa 1887 = Wrl. Lähema mineviku ajalugu. Kohtu asjust. Oma Maa 1, 10. jaanuar, lk 59.

Postimees 1891 = Sõnumid Tallinnast. Postimees 35, 26. märts, lk 3.

Postimees 1906 = Meie aja Agrippa. Postimees 3, 4. jaanuar, lk 2.

Postimees 1921 = Ülikool. Annetus ülikoolile. Postimees 24, 31. jaanuar, lk 2.

Päevaleht 1914 = Imedemaalt. Päevaleht 274, 29. november, lk 6.

Richter 1913 = Richter, Adolf (koost). Adolf Richters Baltische Verkehrs- und Adressbücher 3, Estland. Riga: Selbstverlag des Herausgebers.

Rigasche Rundschau 1906 = Der Prozess Baron Hoyningen-Huene-matzal. Rigasche Rundschau, 23. mai.

Rosenberg, Tiit 2003. Baltisaksa põllumehed Eesti Vabariigis ja Läänemaal 19191939. Läänemaa Muuseumi Toimetised VII. Haapsalu: Läänemaa Muuseum, lk. 2555.

Säde 1906 = Teised ajalehed. Säde 5, 16. märts, lk 3.

Tallinna Sõber 1885 = Omalt maalt. Tallinna Sõber 14, 5. aprill, lk 2.

Tarvel, Enn 1983. Lahemaa ajalugu. Tallinn: Eesti Raamat.

Vahtre, Sulev 1973. Eestimaa talurahvas hingeloenduste andmeil (1782-1858). Ajaloolisdemograafiline uurimus. Tallinn: Eesti Raamat.

Valgus 1906 = Kohtukojast. Valgus 57, 25. mai, lk 3. 
Virulane 1887 = Virumaalt. Virulane 25, 15 juuni, lk 2.

Virulane 1886 = Läänemaalt. Virulane 1, 30. detsember, lk 2.

Wistinghausen, Henning von 1975. Quellen zur Geschichte der Rittergüter Estlands im 18. und 19. Jahrhundert (1772-1889). Hannover: Verlag Hanno v. Hirschheydt.

\section{ABOUT US}

\section{In Matsalu}

Priidik Sarapik's short story from his manuscript entitled Lääne laulik ('Songs and Stories from Läänemaa', 1908).

\section{Who was Priidik Sarapik?}

Laine Soosalu briefly reviews the life events and family of Priidik Sarapik.

\section{The Matsalu Manor and Its Owners}

Historian Tiit Rosenberg, being inspired by the short story by Priidik Sarapik, introduces the Matsalu Manor and its owners, the von Hoyningen-Huenes. 